\title{
Indopadilla, a new jumping spider genus from India (Araneae: Salticidae)
}

\author{
Indopadilla, новый вид пауков-скакунчиков из Индии \\ (Araneae: Salticidae)
}

\author{
John T.D. Caleb ${ }^{1, *}$, Pradeep M. Sankaran ${ }^{2}$, \\ Karunnappilli S. Nafin ${ }^{3}$, Shelley Acharya ${ }^{4}$ \\ Ажкон Т.А. Калеб ${ }^{1,}$, Прадип М. Санкаран ${ }^{2}$, \\ Каруннаппияли С. Нафин ${ }^{3}$, Шемли Ачарья ${ }^{4}$

\footnotetext{
${ }^{1}$ Centre for DNA Taxonomy, Zoological Survey of India, Prani Vigyan Bhawan, M-Block, New Alipore, Kolkata - 700 053, West Bengal, India. Email: caleb87woodgate@gmail.com

${ }^{2}$ Division of Arachnology, Department of Zoology, Sacred Heart College, Thevara, Cochin - 682 013, Kerala, India.

${ }^{3}$ Centre for Animal Taxonomy and Ecology, Department of Zoology, Christ College, Irinjalakuda - 680 125, Kerala, India.

${ }^{4}$ Arachnology Division, Zoological Survey of India, Prani Vigyan Bhawan, M-Block, New Alipore, Kolkata - 700 053, West Bengal, India.

* Corresponding author.
}

KEY WORDS: Aranei, Baviini, description, Darjeeling, Indonesia, new species, taxonomy.

КЛЮЧЕВЫЕ СЛОВА: Aranei, Baviini, описание, Darjeeling, Indonesia, новый вид, таксономия.

ABSTRACT. A new genus Indopadilla Caleb et Sankaran gen.n. is proposed to accommodate three species: I. darjeeling Caleb et Sankaran gen. et sp.n., I. insularis (Malamel, Sankaran et Sebastian, 2015) comb.n. (ex. Bavia) and I. thorelli (Simon, 1901) comb.n. (ex. Bavia). A new species I. darjeeling, the generotype of Indopadilla, is described from West Bengal, India. Additionally, a new combination Bavirecta casteti (Simon, 1900) comb.n. (ex. Piranthus) is proposed.

How to cite this article: Caleb J.T.D., Sankaran P.M., Nafin K.S., Acharya Sh. 2019. Indopadilla, a new jumping spider genus from India (Araneae: Salticidae) // Arthropoda Selecta. Vol.28. No.4. P.567574. doi: 10.15298/arthsel. 28.4.10

РЕЗЮМЕ. Предложен новый род Indopadilla Caleb et Sankaran gen.n. для включения трех видов: I. darjeeling Caleb et Sankaran gen. et sp.n., I. insularis (Malamel, Sankaran et Sebastian, 2015) comb.n. (ex. Bavia) и I. thorelli (Simon, 1901) comb.n. (ex. Bavia). Новый вид $I$. darjeeling, типовой вид рода Indopadilla, описан из западного Бенгала, Индия. Дополнительно, предложена новая комбинация: Bavirecta casteti (Simon, 1900) comb.n. (ex. Piranthus).

\section{Introduction}

The tribe Baviini Simon, 1901 currently includes five genera: Bavia Simon, 1877, Stagetilus Simon, 1885,
Padillothorax Simon, 1901, Piranthus Thorell, 1895 and Bavirecta Kanesharatnam et Benjamin, 2018 [Maddison, 2015; Kanesharatnam, Benjamin, 2018; Prószyński, 2017; 2018]. The SE Asian salticid genus Padillothorax Simon, 1901, which was also included in Simon's 'Bavieae' [Simon, 1901; Prószyński, 2018], was previously considered a junior synonym of Stagetilus Simon, 1885 [Prószyński, 1987] but was recently revalidated [Prószyński, 2017; 2018]; this is why this genus is also included in the Baviini.

While examining unidentified salticid specimens collected over a century ago, in 1916, by F.H. Gravely from the Eastern Himalayas in Darjeeling district, West Bengal State of India, an undescribed species has been recognized. It closely resembles Bavia insularis Malamel, Sankaran et Sebastian, 2015 described from southern India. Superficially, both these species are similar to the baviines in general body shape, with a flattened and broad carapace, elongated and tubular abdomen and enlarged first pair of legs [Maddison, 2015; Kanesharatnam, Benjamin, 2018]. However, these species have a distinct conformation of copulatory organs that does not correspond to any of the previously described genera. To accommodate these two species, as well as Bavia thorelli Simon, 1901 from Indonesia, we propose to erect a new genus, which seems to be close to Padillothorax. Additionally, we propose a new combination for the baviine species Piranthus casteti Simon, 1900 described from Tamil Nadu (India), because it shares a striking resemblance of its copulatory organs to the recently described genus Bavirecta. 

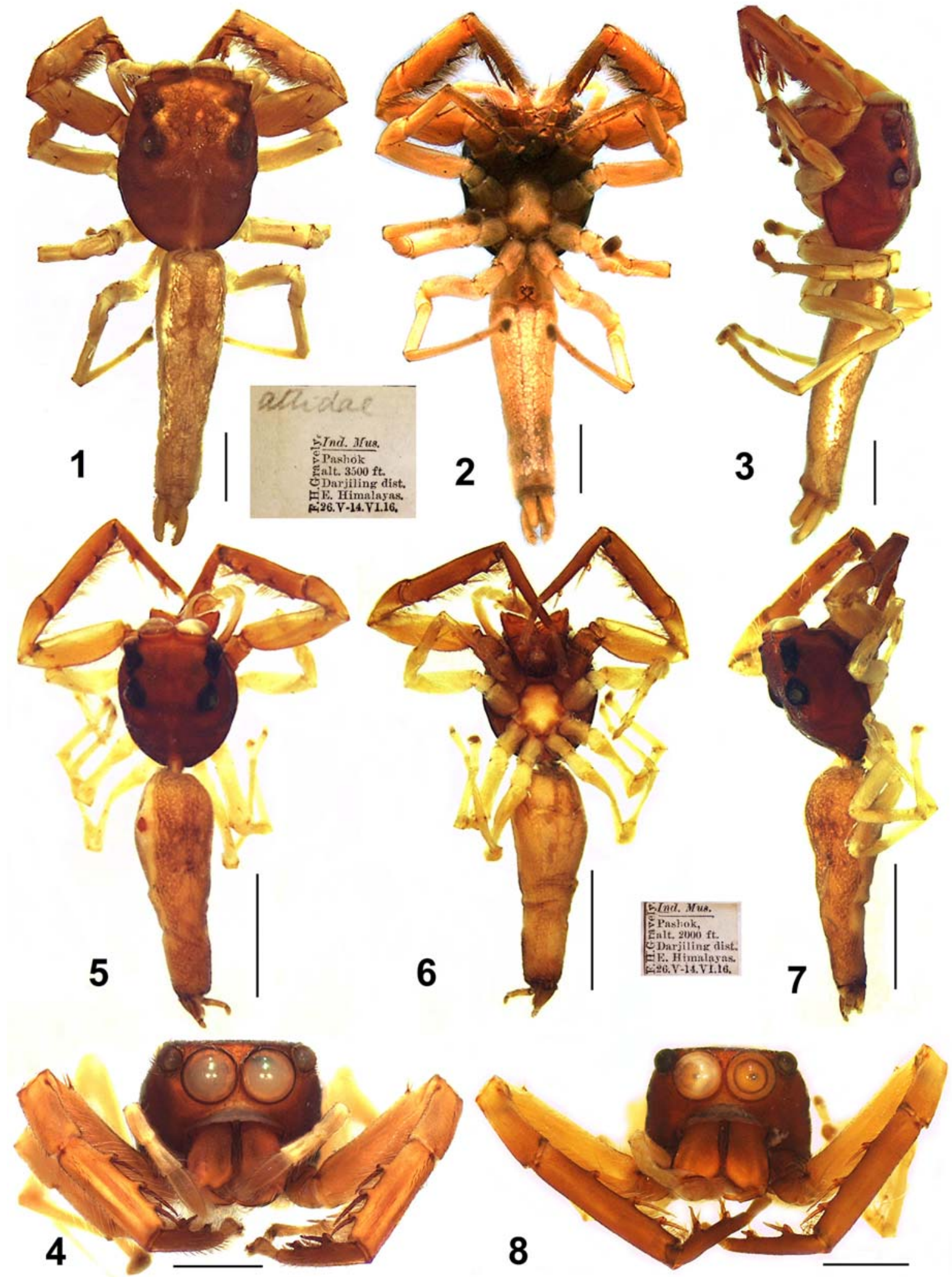

Figs 1-8. Indopadilla darjeeling Caleb et Sankaran gen. et sp.n., holotype female (1-4) and paratype male (5-8): 1, 5 - general appearance, dorsal view; 2, 6 - ditto, ventral view; 3, 7 - ditto, lateral view; 4, 8 - ditto, front view. Scale bars: (1-4, 8) $1 \mathrm{~mm},(5-7) 2$ $\mathrm{mm}$.

Рис. 1-8. Indopadilla darjeeling Caleb et Sankaran gen. et sp.n., голотип-самка (1-4) и паратип-самец (5-8): 1, 5 - общий вид, сверху; 2, 6 - то же, снизу; 3, 7 - то же, сбоку; 4, 8 - то же, спереди. Масштаб: $(1-4,8) 1$ мм, (5-7) 2 мм. 


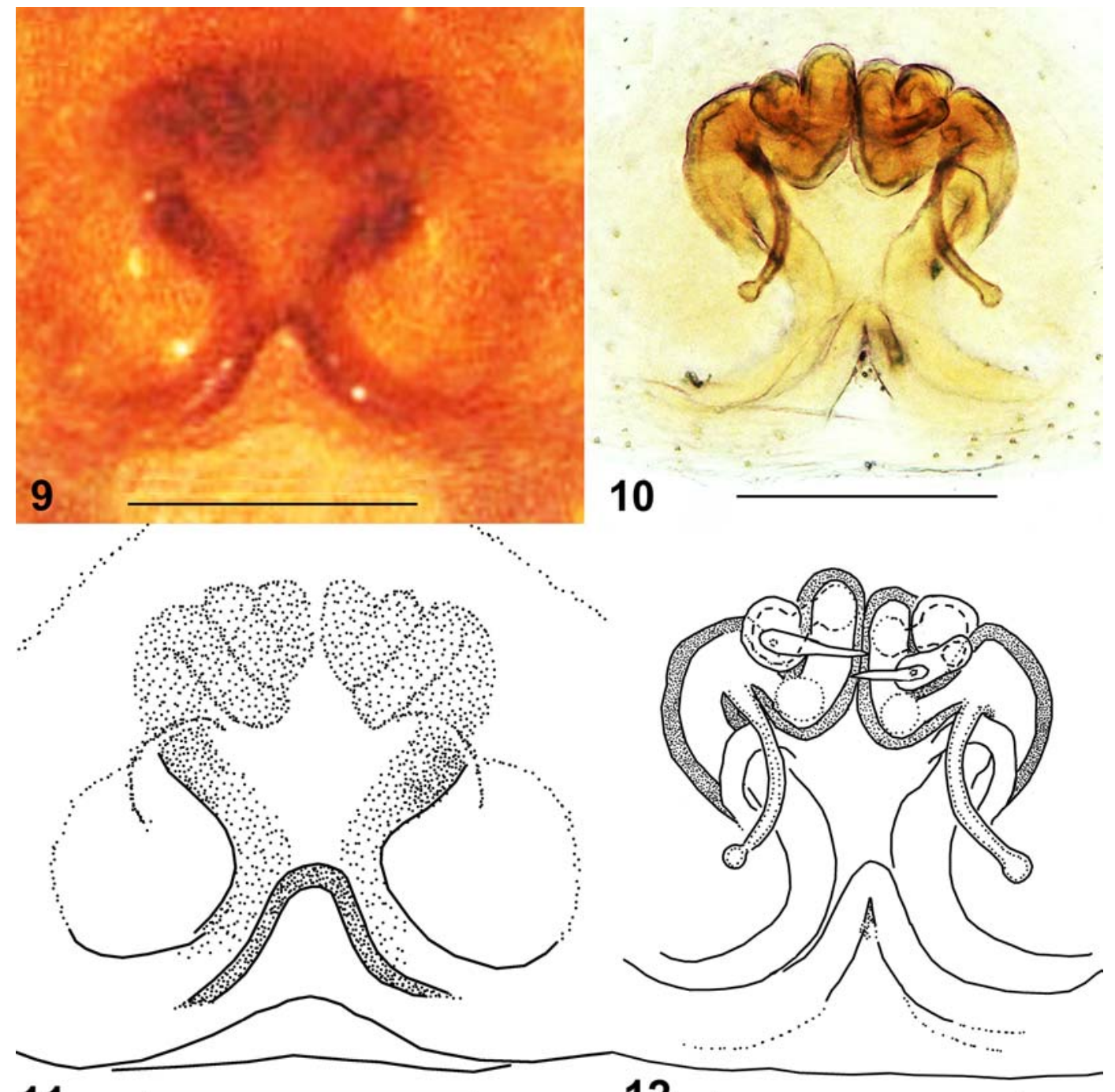

Figs 9-12. Indopadilla darjeeling Caleb et Sankaran gen. et sp.n., holotype female: 9, 11 - epigyne, ventral view; 10, 12 spermathecae, dorsal view. Scale bars: (9-12) $0.2 \mathrm{~mm}$.

Pис. 9-12. Indopadilla darjeeling Caleb et Sankaran gen. et sp.n., голотип-самка: 9, 11 - эпигина, вид снизу; 10, 12 сперматека, вид сверху. Масштаб: (9-12) 0,2 мм.

\section{Material and methods}

Morphological examination and photography were carried out by means of a Leica EZ4 HD stereomicroscope and the images were processed with the aid of the LAS core software (LAS EZ 3.0). Microphotographs of the palps were obtained using a Leica M205A stereomicroscope attached with Leica DFC500 HD camera enabled with a Leica Application Suite (LAS) version 3.8. Epigyne was dissected and macerated in $10 \%$ $\mathrm{KOH}$ to clear soft tissue. Temporary preparation of the epigyne was observed and photographed by means of a Leica DM1000 compound microscope attached with a Leica EC3 camera. Leg measurements are given in the following order: total (femur, patella, tibia, metatarsus, tarsus). Spine positions are as follows: prolateral, dor- sal, retrolateral and ventral. All measurements are in $\mathrm{mm}$. The type specimens are kept in the National Zoological Collections (NZC), Arachnida Section, Zoological Survey of India, Kolkata. The type specimens of Bavia insularis were borrowed from the Division of Arachnology, Department of Zoology, Sacred Heart College, Thevara, Cochin, Kerala, India (ADSH). Additional material on Bavia insularis is kept at the Centre for Animal Taxonomy and Ecology, Christ College, Irinjalakuda, Kerala, India (CATE).

Abbreviations used in the text are as follows: AER anterior eye row; ALE - anterior lateral eye; AME anterior median eye; EFL — eye field length; MNHN Muséum national d'Histoire naturelle, Paris; PER — posterior eye row; PLE — posterior lateral eye; PME — posterior median eye; RTA — retrolateral tibial apophysis. 

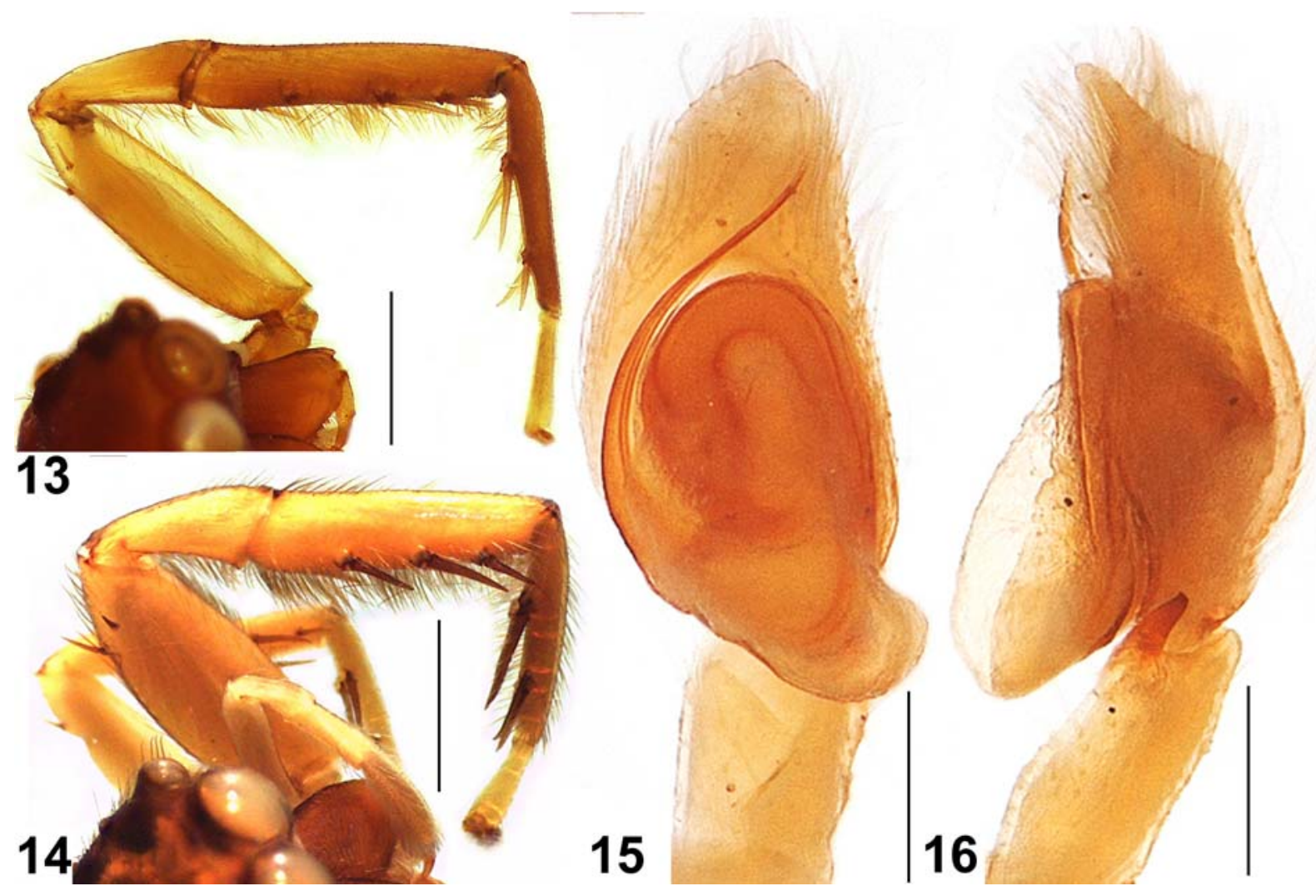

Figs 13-16. Indopadilla darjeeling Caleb et Sankaran gen. et sp.n.: 13 - paratype male, left leg I, prolateral view; 14 - holotype female, left leg I, prolateral view; 15 - male left palp, ventral view; 16 - ditto, retolateral view. Scale bars: $(13,14) 1 \mathrm{~mm} ;(15,16) 0.2 \mathrm{~mm}$.

Рис. 13-16. Indopadilla darjeeling Caleb et Sankaran gen. et sp.n.: 13 - паратип-самец, левая нога I, вид спереди-сбоку; $14-$ голотип-самка, девая нога I, вид спереди-сбоку; 15 - левая пальпа самца, вид снизу; 16 - то же, вид спереди-сбоку. Масштаб: $(13,14) 1$ мм; $(15,16) 0,2$ мм.

\section{Taxonomy}

\section{Genus Indopadilla Caleb et Sankaran gen.n.}

Type species: Indopadilla darjeeling sp.n.

DIAGNOSIS. Indopadilla gen.n. is closely related to the members of the tribe Baviini in having a similar body shape, with a flattened oval carapace, elongated, tubular abdomen and the robust first pair of legs. The males, however, can be readily distinguished from other baviines by the following combination of characters: comparatively longer and slender embolus (Figs 15, 17, 23); RTA medium sized and stout (Figs 16, 18, 24), tegulum with a proximal lobe protruding retrolaterally, without black blotches unlike Bavirecta, and without prolateral lobe of bulbus unlike Bavia and Bavirecta (Figs 15, 17, 23). The females are similar to those of Padillothorax, but can be distinguished by the relatively shorter and uniform insemination ducts unlike the unusual membraneous and broad ducts in the distal portion followed by a narrower and straight proximal portion in Padillothorax. The thin, long accessory glands originate near the distal portion of the insemination ducts and directed posteriorly, whereas in Padillothorax they are situated midway and directed laterally, opposing each other. The spermathecae is tubular and simple (Figs 10, 12, 26), whereas in Padillothorax they are sub-divided or multi-chambered.

ETYMOLOGY. Combination of the prefix 'Indo' (referring to the Indian subcontinent) and 'Padilla' referring its close resemblance to Padillothorax. It is considered feminine in gender.

DESCRIPTION. Carapace oval and flat dorsally (Figs 1, $5,19,20)$. Abdomen elongate, tubular and narrowing posteriorly. Dorsum with light yellow or brown (I. darjeeling) (Figs 1, 5) or black to greyish (I. insularis) (Figs 19, 20), dorso-lateral margins with either continuous or discontinuous longitudinal white patches. The first pair of legs robust, longer and darker than the remaining legs. Tibia I with six thick ventral spines in three pairs, metatarsi I with four ventral spines (Figs 13, 14). Embolus long and tapering gently toward the tip, without membranous margin, tegulum with broad posterior lobe protruding retrolaterally; RTA thick, with broad base and narrow at the tip (Figs 15-18, 23, 24). Epigyne with a posterior medial blind pocket, the copulatory openings present at the anterior portion of rounded or oval epigynal 'windows', insemination ducts accompanied with thin, long accessory glands and small spermathecae (Figs 9-12, 25, 26).

DISTRIBUTION. India, Indonesia.

COMPOSITION. Indopadilla darjeeling Caleb et Sankaran gen. et sp.n., I. insularis (Malamel, Sankaran et Sebastian, 2015) comb.n. and I. thorelli (Simon, 1901) comb.n.

\section{Indopallida darjeeling Caleb et Sankaran sp.n.}

Figs 1-18, Map.

TYPES. Holotype + (NZC-ZSI-6451/18) from India, West Bengal, Darjeeling Distr., Peshok (=Pashok) $\left(27.07^{\circ} \mathrm{N}, 88.39^{\circ} \mathrm{E}\right), 1066$ 


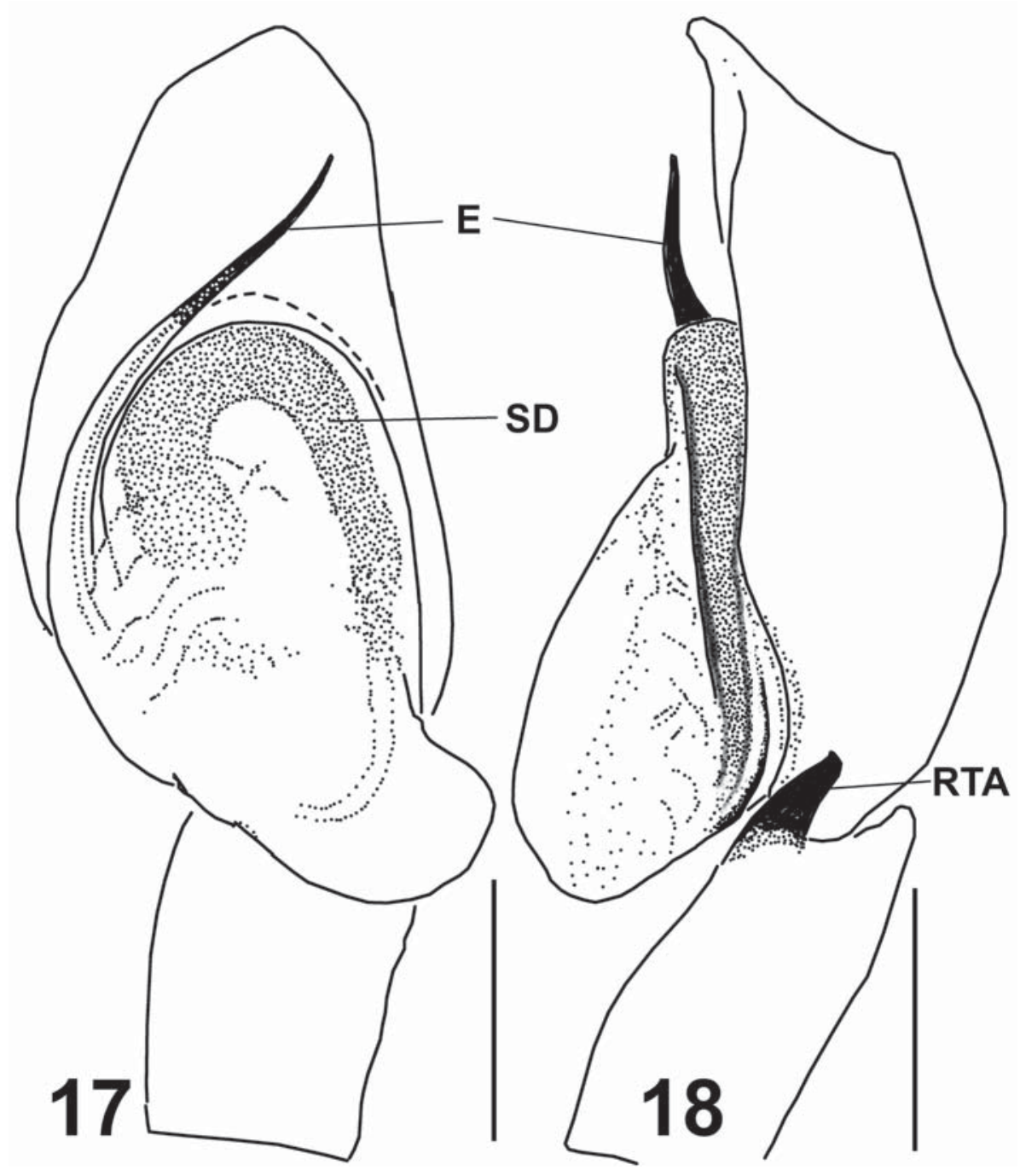

Figs 17-18. Indopadilla darjeeling Caleb et Sankaran gen. et sp.n, paratype male: 17 - left palp, ventral view; 18 — ditto, retolateral view. Scale bars: $(17,18) 0.2 \mathrm{~mm}$. Abbreviations: E — embolus; RTA — retrolateral tibial apophysis; SD — sperm duct.

Рис. 17-18. Indopadilla darjeeling Caleb et Sankaran gen. et sp.n, паратип-самец: 17 — левая пальпа, вид снизу; 18 — то же, вид спереди-сбоку. Масштаб: $(17,18)$ 0,2 мм. Сокращения: Е — эмболюс; RTA - тибиальный отросток; SD - семенной каналец.

m a.s.1., 26.05-14.06.1916, F.H. Gravely. PARATYPES: InDIA: 1 $\mathrm{O}^{7}, 1$ \% (NZC-ZSI-6682/18), the same locality, $610 \mathrm{~m}$ a.s.1., 26.05.14.06.1916, F.H. Gravely.

ETYMOLOGY. The species name is derived from the type locality (Darjeeling), used as a noun in apposition.

DIAGNOSIS. By general body morphology and conformation of the copulatory organs, this species is very similar to I. insularis (Malamel, Sankaran et Sebastian, 2015). The females can be distinguished by the typical dorsum colour pattern: yellowish with continuous whitish sides (Figs 1, 3) (greyish with dorso-lateral discontinuous white patches in $I$. insularis, Fig. 20). The copulatory organs with long and thin ducts of the accessory glands (shorter and wider in I. insularis); the terminal region of the accessory glands with a prominent bulb-like swelling (absent in I. insularis); fertilization ducts directed medially (diverging laterally in I. insularis) (cf. Figs 10, 12 with fig. 19 in Malamel et al. [2015] and Fig. 26 herein). The males can be distinguished by the brownish abdomen with yellowish sides (Fig. 5) (black with discontinuous dorso-lateral white patches in I. insularis, Fig. 19), the first pair of legs are yellow-brown, with lighter yellow femora (Figs 5, 6) (uniformly dark brown in I. insularis; Fig. 19). Palp is almost identical in both species but can be distinguished by the thinner RTA, directed dorsally (broader and thicker in I. insularis, directed apically (cf. Figs 16, 18 with figs 14, 17 in Malamel et al. [2015] and Fig. 24 herein).

DISTRIBUTION. India (West Bengal).

DESCRIPTION. Female (holotype). Total length: 6.39; carapace: 2.63 long, 2.10 wide; abdomen: 3.76 long, 1.01 wide. Carapace brownish, with pale white hairs behind AMEs and longer hairs on the lateral sides of ALEs; eye field covered with yellowish patches; white hairs present behind PLEs; thin patch of white hairs present behind the fovea; posterior eyes surrounded by black patches (Figs 1, 3). Anterior eyes surrounded by pale white orbital setae; clypeus brownish (Fig. 4). Eye measurements: AME 0.65, ALE 0.30, PME 0.09, PLE 0.26, AER 1.78, PER 1.72, EFL 1.20. 


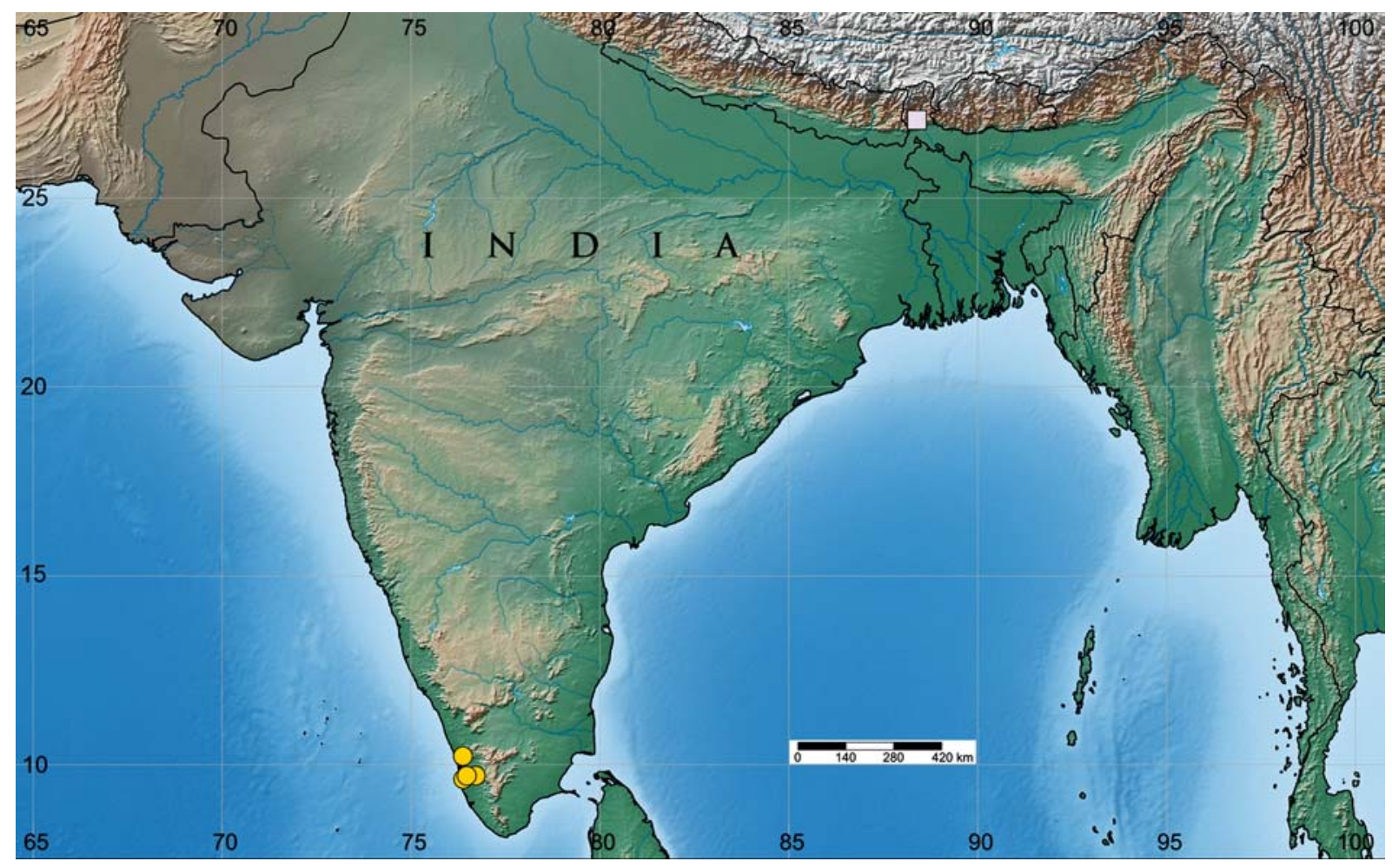

Map. Collecting localities of Indopadilla species from India: I. insularis comb.n. (circles) and I. darjeeling gen. et sp.n. (square). Карта. Тоски находок Indopadilla species из Индии: I. insularis comb.n. (кружки) и I. darjeeling gen. et sp.n. (квадрат).

Clypeus height 0.13 . Sternum oval, yellowish. Chelicerae yellow-brown, with six teeth on the promargin and five small teeth on the retromargin; labium and maxillae yellowish. Legs yellowish; leg I robust, with bunch of ventral thick hairs in the distal region of femora, patellae, tibiae and metatarsi (Figs 1, 3, 14). Leg measurements: I 6.79 (1.91, $1.19,1.65,1.42,0.62)$; II $4.71(1.53,0.84,0.97,0.95,0.42)$; III $4.33(1.49,0.76,0.54,1.06,0.48)$; IV 5.98 (1.83, 0.80, $1.18,1.65,0.52)$. Leg formula: 1423 . Leg spination: femora I 0200, II 0100, III 0100, IV 0200; patellae I-IV 0000; tibiae I 0006, II 2001, III-IV 0000; metatarsi I 0004, II 0004, III-IV 0000; tarsi I-IV 0000. Abdomen brownish, with white lateral sides; mid-dorsum with light brown chevron-shaped markings (Fig. 5). Spinnerets yellowish. Palps yellow-brown, covered with pale white hairs. Epigyne with a distinct posterior medial pocket; copulatory openings present above the oval 'windows'; insemination ducts broad, with thin, long accessory glands terminating with a small bulb-like swellings (Figs 9-12).

MALE. Total length: 5.79; carapace: 2.14 long, 1.90 wide; abdomen: 3.65 long, 1.13 wide. Eye measurements: AME 0.58, ALE 0.28, PME 0.07, PLE 0.25, AER 1.65, PER 1.58, EFL 1.07. Clypeus height 0.09. Leg measurements: I 7.84 (2.14, 1.22, 2.01, 1.68, 0.79); II 4.61 (1.41, 0.76, 0.92, 1.01, $0.51)$; III 4.02 (1.34, 0.67, 0.57, 0.99, 0.45); IV 5.20 (1.51, $0.66,1.06,1.43,0.54)$. Leg formula: 1423 . Leg spination: femora I 0200, II 0100, III 0100, IV 0200; patellae I-IV 0000; tibiae I 0006, II 0003, III-IV 0000; metatarsi I 0004, II 0004, III-IV 0000; tarsi I-IV 0000. Coloration as in the female (Figs 5-8). Palps yellowish, covered with pale white hairs; embolus long and ending at one o'clock position ventrally, RTA strong, narrowing distally, with retrolaterally directed angular tip (Figs 15-18).

\section{Indopadilla insularis (Malamel, Sankaran et Sebastian, 2015) comb.n. Figs 19-26, Map.}

Bavia insularis Malamel, Sankaran et Sebastian, 2015: 597, figs 1-2, 4-20 (D $\bigcirc^{7}$ ) $)$ the type series in ADSH, examined.

TYPES. Holotype $O^{7}$ (ADSH856501) from India, Kerala, Alappuzha, Pathiramanal Island $\left(9^{\circ} 37^{\prime} 07.11^{\prime \prime} \mathrm{N}, 76^{\circ} 23^{\prime} 04.95^{\prime \prime} \mathrm{E}\right), 0 \mathrm{~m}$ a.s.1., 27.03.2015, M.S. Pradeep \& M.J. Jobi. PARATYPES: INDIA: $3 \sigma^{2} \sigma^{7}, 6$ 우 (ADSH856502), together with the holotype.

OTHER MATERIAL. INDIA: $1 \sigma^{7}, 2$ Oᄋ (CATE), Kerala, Ernakulam, Aluva, Aluva Manalpuram ( $\left(10^{\circ} 07^{\prime} 21.1^{\prime \prime} \mathrm{N} 76^{\circ} 21^{\prime} 07.4^{\prime \prime} \mathrm{E}\right)$, $2 \mathrm{~m}$ a.s.1., 20.09.2015, K.S. Nafin; $3 \sigma^{7} \sigma^{7}, 2$ 우 (CATE), Kerala, Thrissur, Nedumpal, Konthipulam $\left(10^{\circ} 23^{\prime} 20.2^{\prime \prime} \mathrm{N} 76^{\circ} 14^{\prime} 31.7^{\prime \prime} \mathrm{E}\right) 0$ $\mathrm{m}$ a.s.l., 11.10.2016, K.S. Nafin; 1 (CATE), Irinjalakuda, Thrissur, Christ College $\left(10^{\circ} 21^{\prime} 27.3^{\prime \prime} \mathrm{N} 76^{\circ} 12^{\prime} 47.5^{\prime \prime} \mathrm{E}\right), 30 \mathrm{~m}$ a.s.l., 26.07.2015, K.S. Nafin \& P.P. Sudhin.

REMARKS. The species was originally described and placed in Bavia by Malamel et al. [2015], who also indicated that the genus was in need of revision, since many of its species were unrelated to the generotype (see also Żabka [1988] and Prószyński \& Deeleman-Reinhold [2013]). This species is very close to its congener from Darjeeling, but differs significantly in details of the copulatory organs (see 'Diagnosis' above). The copulatory opening is present in the anterior region of the epigynal 'window', similar to that of $I$. darjeeling, but the duct course is different (it was incorrectly interpreted by Malamel et al., 2015; cf. Fig. 20).

\section{Indopadilla thorelli (Simon, 1901) comb.n.}

Bavia thorelli Simon, 1901: 461, fig. 532 (D $\left.\bigcirc^{7}\right)$; the holotype $\mathrm{O}^{7}$ is not re-examiend. 

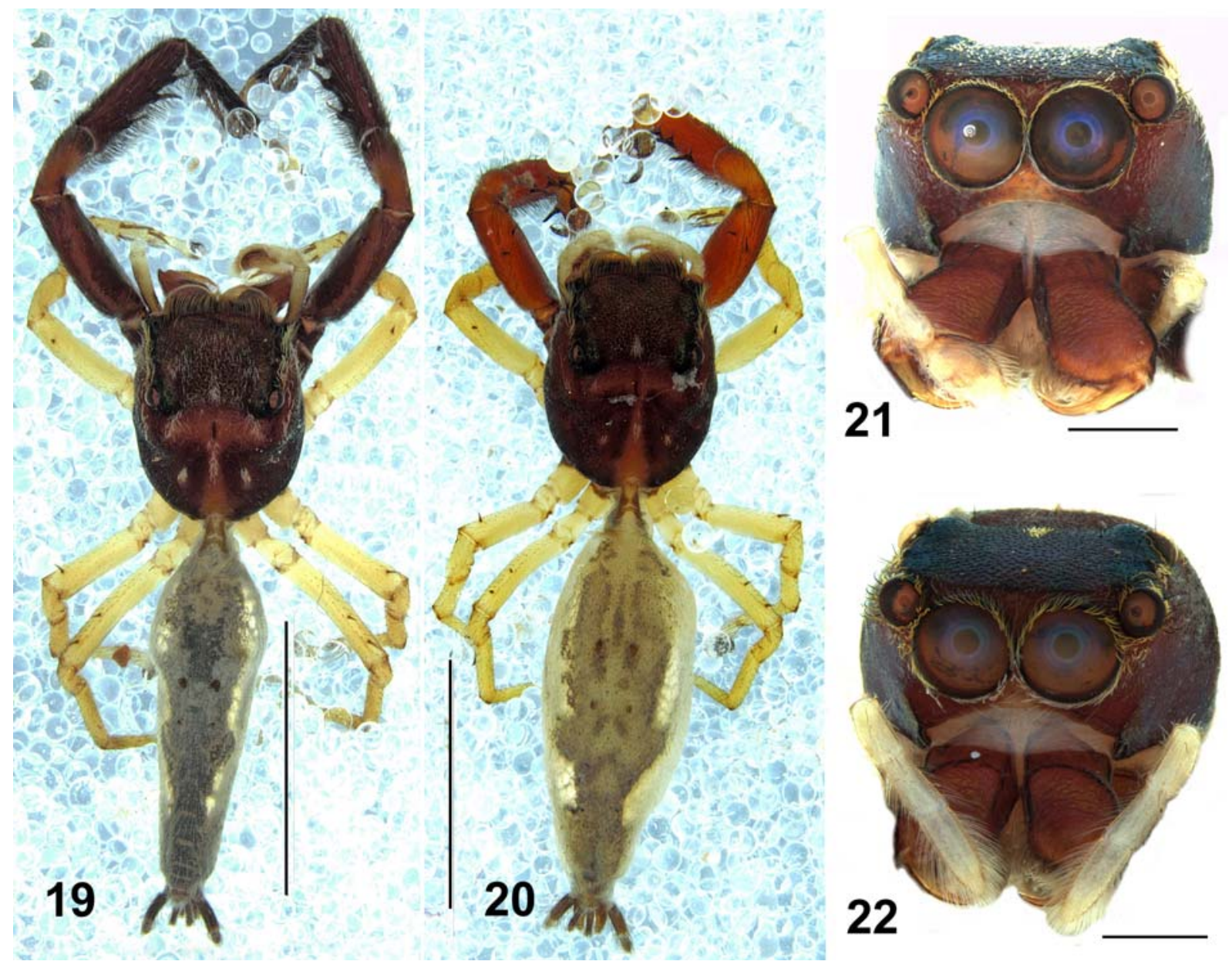

Figs 19-22 Indopadilla insularis (Malamel, Sankaran et Sebastian, 2015) comb.n. from Kerala: 19 - male, dorsal view; 20 female, dorsal view; 21 - male, front view; 22 - female, front view. Scale bars: $(19,20) 5 \mathrm{~mm},(21,22) 1 \mathrm{~mm}$.

Рис. 19-22 Indopadilla insularis (Malamel, Sankaran et Sebastian, 2015) comb.n. из Кералы: 19 - самец, вид сверху; 20 самка, вид сверху; 21 - самец, вид спереди; 22 - самка, вид спереди. Масштаб: $(19,20) 5$ мм, (21, 22) 1 мм.

Bavia thorelli: Simon, 1902: 24 (D $\left.\sigma^{7}\right)$; Żabka, 1988: 440, figs 52-55 $\left(\mathrm{D}^{7}\right)$; the latter author re-examined and illustrated the holotype.

REMARKS. The species was originally described by Simon [1901] from Minahassa (=Minahasa), Indonesia. Żabka [1988], who erroneously provided the locality for this species as Sri Lanka, redescribed the holotype $\sigma^{7}$ and remarked that its generic placement is "doubtful and should be treated as temporary". Based on the similar palpal morphology with $I$. darjeeling and $I$. insularis and the resemblance of the abdominal colour pattern with I. insularis, it is safe to transfer this species name to the newly erected genus.

\section{Bavirecta casteti (Simon, 1900) comb.n.}

REMARKS. The species was first described by Simon in 1900 from South India. Based on the re-examination of the type deposited in MNHN, Paris, the female copulatory organs of this species were illustrated by Prószyński [1987]. The spermathecae differ considerably from those of the generotype of Piranthus - P. decorus Thorell, 1895 (cf. figs in Prószyński, 1987: 87 with figs 2F, 3B in Caleb \& Sanap [2017]) - but are rather similar to those of Bavirecta fla- vopuncta Kanesharatnam et Benjamin, 2018, the generotype of Bavirecta, in having the simple copulatory openings, the relatively shorter, wider and sclerotized insemination ducts and the compact spermathecae. However, it can be distinguished from $B$. flavopuncta by the elongate, almost slitlike, laterally directed copulatory openings (rounded and anteriorly directed in B. flavopuncta), the bean-shaped spermathecae (pear-shaped in B. flavopuncta), and the fertilization ducts which arise from the anterior region of the spermathecae (from mid-lateral walls in B. flavopuncta) (cf. figs 2C, D in Kanesharatnam \& Benjamin [2018]).

Acknowledgements. We are grateful to Dr Kailash Chandra, Director of the Zoological Survey of India for his support and for providing the necessary facilities to carry out the work. Thanks are due to Mr Chandan Bera for the curatorial assistance and sorting unidentified salticid collections from the Arachnida section. JC thanks the American Arachnological Society for awarding him with the Herb Levi Memorial Fund for Arachnological Research (HLMFAR) grant. Our wholehearted thanks go to Dr Dmitri Logunov (Manchester, UK) for his supportive comments on the ms. 


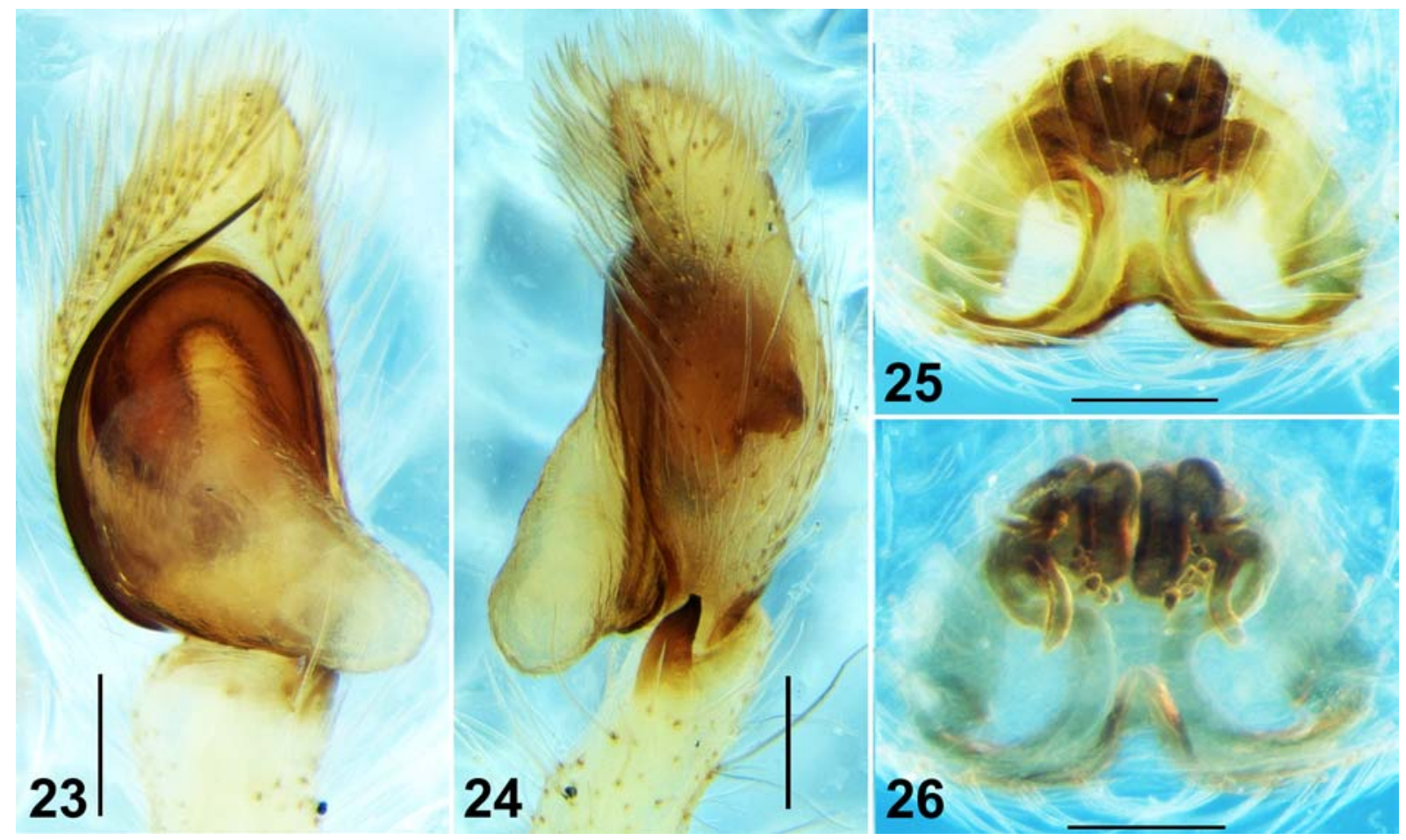

Figs 23-26 Paratypes of Indopadilla insularis (Malamel, Sankaran et Sebastian, 2015) comb.n. from Kerala: 23 - male left palp, ventral view; 24 - ditto, retolateral view; 25 - epigyne, ventral view; 26 - spermathecae, dorsal view. Scale bars: $(23,24) 0.25 \mathrm{~mm},(25,26)$ $0.20 \mathrm{~mm}$.

Рис. 23-26 Паратипы Indopadilla insularis (Malamel, Sankaran et Sebastian, 2015) comb.n. из штата Керала: 23 - левая пальпа самца, вид снизу; 24 - то же, вид спереди-сбоку; 25 - эпигина, вид снизу; 26 - сперматека, вид сверху. Масштаб: $(23,24) 0,25$ мм, $(25,26) 0,20$ мм.

\section{References}

Caleb J.T.D., Sanap R.V. 2017. Rediscovery of Piranthus decorus Thorell 1895 (Araneae: Salticidae) after 122 years since the original description // Acta Arachnologica. Vol.66. No.1. P.2529.

Kanesharatnam N., Benjamin S.P. 2018. A new genus and three new species of jumping spiders (Araneae: Salticidae) from $\mathrm{Sr} i$ Lanka // European Journal of Taxonomy. Vol.444. P.1-24.

Maddison W.P. 2015. A phylogenetic classification of jumping spiders (Araneae: Salticidae) // Journal of Arachnology. Vol.43. No.3. P.231-292.

Malamel J.J., Sankaran P.M., Sebastian P.A. 2015. First record of the jumping spider genus Bavia Simon, 1877 from India, with the description of a new species // Zootaxa. Vol.4007. No.4. P.596-599.

Prószyński J. 1987. Atlas rysunków diagnostycznych mniej znanych Salticidae 2. Zeszyty Naukowe Wy ¿szej Szkoly Rolniczo-Pedagogicznej, Siedlcach, $172 \mathrm{pp}$.

Prószyński J. 2017. Pragmatic classification of the world's Salticidae (Araneae) // Ecologica Montenegrina. Vol.12. P.1-133.

Prószyński J. 2018. Review of genera Evarcha and Nigorella, with comments on Emertonius, Padilothorax [sic], Stagetillus, and description of five new genera and two new species (Araneae: Salticidae) // Ecologica Montenegrina. Vol.16. P.130-179.
Prószyński J., Deeleman-Reinhold C.L. 2013. Description of some Salticidae (Araneae) from the Malay Archipelago. III. Salticidae of Borneo, with comments on adjacent territories // Arthropoda Selecta. Vol.22. No.2. P.113-144.

Simon E. 1877. Etudes arachnologiques. 5e Mémoire. IX. Arachnides recueillis aux îles Phillipines par MM. G. A. Baer et Laglaise // Annales de la Société Entomologique de France. Vol.7. P.53-96.

Simon E. 1885. Arachnides recueillis par M. Weyers à Sumatra. Premier envoi // Annales de la Société Entomologique de Belgique. Vol.29. P.30-39.

Simon E. 1900. Descriptions d'arachnides nouveaux de la famille des Attidae // Annales de la Société Entomologique de Belgique. Vol.44. P.381-407.

Simon E. 1901. Histoire naturelle des araignées. Paris. Vol.2. P.381668.

Thorell T. 1895. Descriptive catalogue of the spiders of Burma. London. 406 p.

World Spider Catalog 2019. World Spider Catalog. Natural History Museum Bern, online at http://wsc.nmbe.ch, version 20.0 [accessed 20 March 2019].

Żabka M. 1988. Salticidae (Araneae) of Oriental, Australian and Pacific regions, III // Annales Zoologici, Warszawa. Vol.41. P.421-479.

Responsible editor D.V. Logunov 